\title{
7
}

\section{The Way Forward: A Stakeholder Analysis}

\subsection{Introduction}

This book presents a comprehensive overview of the housing market dynamics in Africa. It highlights the many facets of the housing market challenges on the continent: rapid urbanization, poor urban planning, dysfunctional land markets, rising construction costs, proliferation of informal settlements, underdeveloped financial systems, and the problem of affordable housing supply. While many of these issues are prevalent in most countries, the extent of these problems varies from one country to the next, and across regions. However, beneath these challenges also lie opportunities. In most economies in other regions of the world, rapid urbanization has been accompanied by structural transformation, characterized by a move of resources first from agriculture into industry and services, and then later from agriculture and industry into services. In developing Asia, as in North America and Europe, urbanization was accompanied by substantial economic growth and development. If properly harnessed, Africa's rapid urbanization could also foster the development of efficient and sustainable cities, as well as accelerate inclusive growth and job creation. We estimate that addressing Africa's housing crisis has the potential to create 288 million full-time-equivalent jobs in 
10 years and add US\$5.07 trillion to the economy for an investment of US\$2.08 trillion during the same period.

Thus far, Africa's housing sector has failed to adequately accommodate the needs of low- and middle-income families. As a result, moving up the property ladder is as challenging as getting a first foot on it. In many countries, house prices are out of reach for a majority of the population. New data in our study revealed that the average cost of an entry-level house of $40 \mathrm{~m}^{2}$ in Africa is US\$16,495. At this price, 33 percent, or 76 million, African households cannot even get a foot on the housing ladder. Providing affordable housing options to low- and middle-income families is imperative for the development of Africa's housing market, and for addressing the continent's huge housing backlog. Expanding the supply of affordable housing will require policies and regulations that address the root causes of Africa's dysfunctional housing market. It is also crucial to consider the broader development objectives in the choice of solutions aimed at lowering housing costs.

In Chap. 3, we explored the constraints of access to finance faced by consumers, real estate developers, and financial intermediaries along the housing value chain. In drawing linkages between the formal and informal housing finance markets, the chapter sheds some light on innovations being offered to support low-income households in the informal sector in climbing onto or moving up the housing ladder. Chapter 4 drilled down on three key challenges impeding the supply of affordable land in Africa. The chapter also argues that the provision of basic infrastructure, especially transport infrastructure, not only shapes cities, but is an important determinant of housing affordability, particularly for lowincome families. Chapter 5 discussed five key approaches to reducing construction costs in Africa, including industrializing housing construction, promoting densification, and producing and using local building materials, among others. Chapter 6 examined enabling approaches for slum upgrading and housing alternatives for households at the bottom of the housing ladder. The chapter emphasizes the need to develop housing rental markets, given that not everyone can be a homeowner.

In this concluding chapter, we draw on findings in previous chapters and lessons learned from other emerging countries and regions to provide policy suggestions to key stakeholders involved in Africa's housing market. Given the breadth and depth of Africa's housing problem, finding 
sustainable solutions to the continent's affordable housing crisis will require well-coordinated and concerted efforts from all stakeholders, including the public, private, and nonprofit sectors.

\subsection{Role of Government}

The importance of policy and regulation in shaping housing markets cannot be overemphasized. As Fig. 5.4 shows, the government plays an important crosscutting role in the housing market, intervening in all of the steps of the housing delivery value chain. Building standards, energyefficiency requirements, competing land usage demands, provision of bulk infrastructure, housing finance, subsidy programs, and the need for sustainability in new housing projects all have an immense impact on the housing market. Besides affecting the quantity of housing supplied, these policies have a significant bearing on housing affordability. Overall, policies and regulation can result in important changes in the functioning and performance of the housing market. Governments have a long history of supporting affordable housing across the globe. The Malaysian national mortgage corporation, Cagamas, the United States' Federal National Mortgage Association (Fannie Mae) and Federal Home Loan Mortgage Corporation (Freddie Mac), South Africa's National Housing Finance Corporation, and Morocco's FOGARIM guarantee program are but a few examples from a long list of institutions and programs created by governments to encourage homeownership and increase housing affordability.

Africa's housing crisis can be solved only by the unwavering commitment and political will of national governments, given the long-term nature of housing assets. Morocco provides a concrete example of how restructuring the relationship between the state, the private sector, and the community can accelerate progress in easing the housing crisis. The strong political will demonstrated by the Ethiopian government in its Integrated Housing Development Program is another notable example. The starting point for government support should focus on creating an enabling environment that induces private agents and nongovernmental organizations to build and finance housing acquisition for all household segments, especially low- and middle-income families. Several governments in Latin America, such as that of Chile, have adopted the 
enabling approach to successfully reform their housing policies and systems.

In Africa today, an enabling market approach will require an overhaul of government housing policies, institutions, laws, and regulations in order to support a well-functioning and efficient housing market. The enabling approach changes the role of government from a provider of housing, which it had not been effective in fulfilling in most cases, to that of a facilitator. In the context of the housing delivery value chain discussed earlier, the roles of government can be grouped into three categories: regulator, input provider, and facilitator.

\subsubsection{Government as Regulator}

Effective and streamlined regulations with the right institutional setup and implementation are necessary throughout the value chain and will determine the effectiveness of housing markets in Africa. Here, we focus on a few key policy areas.

\subsubsection{Urban Planning}

Perhaps the most important regulatory tool at governments' disposal for guiding urbanization and city growth is urban planning. It is the policy that defines the use of land, the design of urban infrastructure, communication networks and provisions that provides protection of the natural environment. It also provides mechanisms for urban expansion and for making land available for housing development. It is the absence of up-to-date urban plans and/or the effective enforcement of existing plans that have led to urban sprawl and unplanned growth in many African cities. These conditions have led to a scarcity of welllocated lands for housing and to cost escalations for land, infrastructure, and housing. Therefore, to improve the efficiency of cities and enable them to fully play their economic role, African governments should regularly update their urban plans and ensure that they are grounded in local realities. 


\subsubsection{Housing Policies}

Housing policies include governments' regulations and actions that affect the demand and supply of housing. In an enabling environment, regulations should promote the efficient functioning of different segments of housing markets. For instance, very stringent quality standards may well be appropriate for high-rise luxury apartments, but the same standards for less luxurious units may make housing unaffordable for low-income households. Similarly, plot size requirements copied from colonial powers in the 1950s and 1960s push the majority of households into the informal housing sector as the formal one becomes unaffordable. Although the list of possible recommendations for effective housing policies is long, we focus on three key policies that have significant effects on housing access and affordability: property rights, housing finance, and construction efficiency.

\section{Promoting Property Rights}

Notwithstanding the validity of the continuum of land rights, the largescale housing provision needed in most countries will be difficult to realize without clear property rights based on secure land titles. Secure property rights are not only important for the supply side, but also crucial for a well-functioning housing finance market. Governments should enact streamlined frameworks that provide for individual property rights and facilitate the ability to transfer these rights. Computerized central information systems and decentralized mechanisms for registration and transfer of property will lower the time and costs involved in the process and improve security. Rwanda's approach in overhauling its property registration system should be considered by other countries' governments.

In addition, governments should enact clear procedures for registering property as collateral and for realizing such collateral when necessary. Building such information systems is particularly important for the development of secondary mortgage markets, wherein the legitimacy of underlying assets and securities needs to be ascertained. Moreover, a system that is accessible to financial institutions, insurers, investors, land registries, and 
other relevant stakeholders will help eliminate the use of the same collateral for multiple loans and reduce the use of forged documents to obtain loans. However, the protection of property rights and secured collateral systems are effective only if the judicial system is independent and capable of enforcing contracts. Establishing a separate system that deals specifically with property rights and collateral claims related to housing may be an effective way to jump-start the mortgage market.

\section{Promoting Inclusive Housing Finance Systems}

To deepen housing finance markets, laws regarding securitization, bankruptcy and collateral reforms, sound frameworks for collateral valuation practices, an overhaul of credit registry systems, and housing information systems are needed. Two types of regulations have a large bearing on housing finance systems. The first is regulation of the activities of banks, microfinance institutions (MFIs), and other nonbanking financial institutions (NBFIs) that can broaden and deepen housing finance systems. For instance, regulations limiting the share of holdings of different types of assets can be used to promote inclusive mortgage systems. In Kenya, the simple requirement of having banks report their mortgage assets has pushed some institutions to increase their exposure to the sector.

Given the right regulations, NBFIs can play a vital developmental and complementary role to banks in housing finance systems. Institutions such as pension funds, insurance firms, housing finance companies, mortgage liquidity facilities, and private equity vehicles are risk-pooling institutions that can mobilize long-term finance and address the liquidity needs of the housing market. Financial sector policies and regulations should permit these institutions to invest in the housing sector, including rental housing. Legal and regulatory reforms that strengthen borrower and creditor rights, bolster credit analysis, and promote sound macroeconomic management are essential for expanding housing finance markets. Moreover, prudential requirements and conversion ratios of short-term liabilities have an important effect on housing finance. However, a balance between the promotion of lending and prudent management of systemic risks is necessary. 
The second type of regulation with a large impact on housing finance is fiscal policy. Fiscal incentives such as tax exemptions and a housing finance guarantee fund accelerate the construction and uptake of housing for low-income households. Morocco provides vivid examples on how policy reforms accompanied by institutional and fiscal incentives can accelerate the production of affordable housing by private developers. The Finance Law of 2010, which was renewed in 2013, exempts lowincome housing developers from paying corporate taxes, value added tax, cement taxes, and land registration fees. In addition to these tax exemptions, the government also offers incentives to homebuyers. For instance, housing for middle-class households is exempt from registration fees for property titles, as well as stamp duty and fees on land. In Senegal, housing cooperatives and social housing developers pay a value added tax rate of 10 percent, as compared with the standard rate of 20 percent. Other tax breaks include a 5 percent tax rate for affordable housing developers and 1 percent for housing cooperatives, whereas the standard construction tax is 15 percent.

\subsubsection{Promoting Efficiency in Housing Construction and the Use of Local Building Materials}

As discussed in Chap. 5, cumbersome and poorly targeted regulations lengthen construction times, increase costs, and promote corruption, which inherently lead to an inefficient housing delivery process. Through in-depth analysis and discussions with stakeholders, governments should identify gaps and streamline processes to improve efficiency and lower construction costs. For instance, the government of Kenya was able to reduce considerably the time it takes to obtain a construction permit by adopting an online process. Moreover, regulations related to building standards, plot sizes, and standards for building materials should be flexible and should meet the needs of not only high-income households but also those at the bottom of the housing ladder.

Policy proposals should also promote the use of local building materials such as compressed stabilized earth blocks, bamboo, and laminated wood. In general, despite being cheaper, such local materials are not 
widely used because of market failures and the poverty stigma associated with the use of these materials. Our analysis has also shown that heavy imports of building materials are contributing to rising construction costs. Therefore, governments should use strategic trade policy to promote local production of building materials, which will contribute to the development objectives of many governments to industrialize and create jobs for their growing labor forces. Ethiopia and Rwanda are moving in this direction, and we recommend other countries to follow suit and work together to create common standards to promote regional trade through economies of scale.

\subsubsection{Government as Input Provider}

Even though the government should mainly focus on its role as regulator, there are inputs that the private sector either cannot provide or provides at higher costs. We recommend that governments focus on two main inputs:

- Bulk infrastructure: Because of its public good characteristics and large initial investment requirements, bulk infrastructure (primary roads, electricity, water, and sanitation) is best provided by the public sector. Governments should create mechanisms to ensure that all new housing developments are connected to the bulk infrastructure networks, which will reduce the proliferation of slums, which are characterized by unsanitary living conditions. Urban planning can lower the costs of such infrastructure as good planning anticipates and builds infrastructure before housing settlements, as opposed to the current sequence in most African cities. Given the fiscal pressure on governments, we recommend that policymakers explore the possibility of financing bulk infrastructure through municipal bonds and of recouping investments through land value capture. It is also possible to recoup part of the costs of infrastructure provision in slum-upgrading programs through various levies and cost-sharing arrangements.

- Land and finance for affordable housing projects: Given the high land prices and construction costs, formal housing is unaffordable to the 
majority of low- and middle-income Africans. Governments in various countries have been working with the private sector in affordable housing projects by contributing land as well as finance through various subsidies and tax policies. If well structured, these public-private partnerships (PPPs) can increase the supply of affordable housing with minimal effect on government revenues. On the demand side, we believe that guarantee schemes, such as FOGARIM in Morocco, provide a great opportunity to leverage private-sector funding to reach specific segments of the population. We emphasize the need for strong governance and good targeting of government programs that have input elements. There are various examples of social housing programs that have benefited the rich and well connected, so a systematic approach should include well-designed targeting and monitoring mechanisms that primarily benefit underserved households.

\subsubsection{Government as Facilitator}

Increasing the efficiency of the housing sector in Africa requires a value chain approach with close coordination between various stakeholders. The government can play a pivotal role in facilitating such coordination and ensuring all stakeholders work together. The government can also promote best practices from other countries and provide valuable information to builders and households on various issues. For instance, in many countries, a poverty stigma is preventing the adoption of local materials. The government can help to remove such stigma through information campaigns and through demonstration effects in its public buildings. The government can also facilitate partnerships in slumupgrading and affordable housing programs.

Another role of the government is to provide training in the needed skills in the construction sector. As discussed in Chap. 5, the shortage of skills in many countries is having a negative impact on the costs and quality of housing. Governments need to increase the technical and vocational training of youth in the various skills needed by the construction and manufacturing sectors, among others. This type of training should be done in close partnership with the private sector to ensure that needs are identified correctly and training is delivered effectively. 


\subsection{Role of the Private Sector}

The private sector is a key partner to governments and nonprofits in scaling up the supply of affordable housing. Essentially, the private sector should be at the forefront of developing, innovating, and financing affordable housing solutions. As the government creates a better enabling environment, the private sector needs to improve its processes to increase efficiency and capacity to deliver at scale. The construction sector in many countries is currently dominated by SMEs that lack the capacity to build more than 500 housing units a year. Better linkages between firms of different sizes and capacity-building programs through industry organizations can improve both the capacity and productivity of the sector. Industry organizations also need to promote best practices and combat inertia and resistance to change, which is endemic in the construction sector. Moreover, better industrial organization with a greater role for prefabrication of building systems can boost productivity and lower construction times and costs. However, for this to work, the regulatory environment needs to be supportive as, for example, through standardizing building codes and dimensions of housing components.

On the financing side, the financial sector should develop new and innovative solutions for serving low- and middle-income households. As standard mortgages are not the solution for all housing segments, other products such as incremental building loans should be developed for lowincome households. In addition, more work needs to be done to better understand and serve households in the informal sector that may have decent incomes yet are entirely excluded from housing finance.

\subsection{Role of Development Partners}

Given the sobering facts of Africa's housing crisis, and the large economic and employment multiplier effects of housing construction, DFIs such as the AfDB and the World Bank Group have a fundamental role to play in addressing the continent's housing needs (see Table 7.1 below). The housing sector represents an opportunity for these organizations to achieve 
their larger development goals of industrializing Africa, and improving the life of African people for the AfDB, and reduce poverty for the World Bank.

The intervention of development partners should focus on improving the housing conditions of low-income households, promoting efficiency, and supporting innovative solutions to address the continent's colossal housing shortage. The subsequent paragraphs provide a few priority areas for development partner interventions. Based on these policy recommendations, the AfDB should develop operational guidelines for its housing sector as part of its urban development strategy.

\subsubsection{Support Government in Its Role as Regulator}

The previous discussion emphasized the crucial role of the government to design and implement effective regulations to improve the efficiency of the housing sector in Africa. However, in many instances, governments lack the institutional, human and financial capacity to fulfill this mission. Therefore, development partners should assist governments in fulfilling this role. Specifically, DFIs should assist governments in training urban planners and should provide financial assistance, if necessary, for updating urban plans. Given the importance of effective land governance systems, DFIs should assist governments in setting up appropriate institutions for land management. Given their large cross-country focus, DFIs are in a good position to assist in the transfer of lessons learned from other countries in Africa and globally. A key reform with great potential benefits is the use of computerized land registry and transfer systems. Assistance from DFIs in designing and implementing such systems can improve the functioning of land and housing markets. Similarly, a computerized approval process for building permits has shown great effect in reducing time and cost, as well as in improving transparency.

Our research has also shown that most African governments have an acute shortage of building inspectors. This often leads to delays and corruption, resulting in the lack of application of building codes, which has led to deadly accidents in some countries. Improved capacity and governance in this area is urgently needed. 


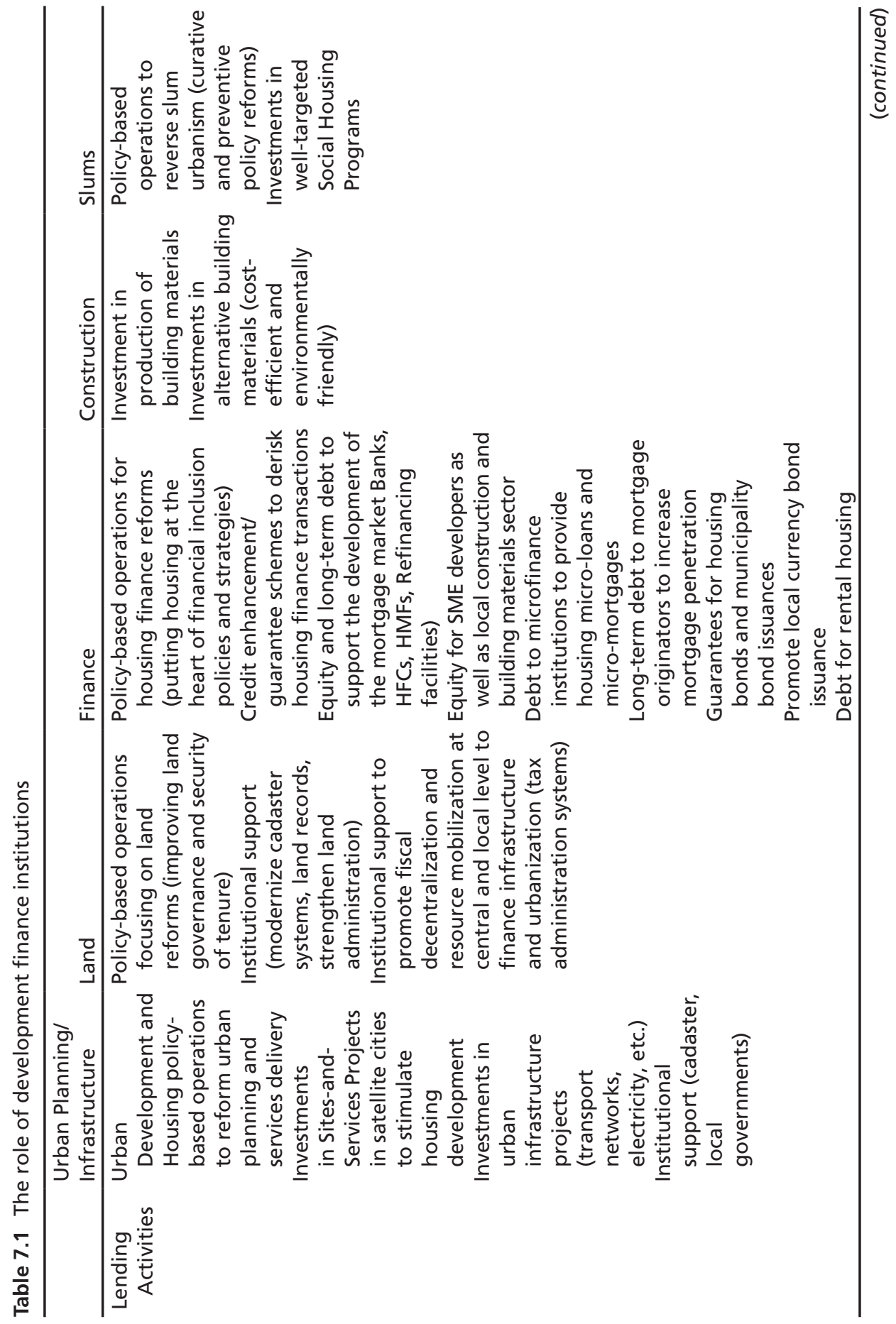




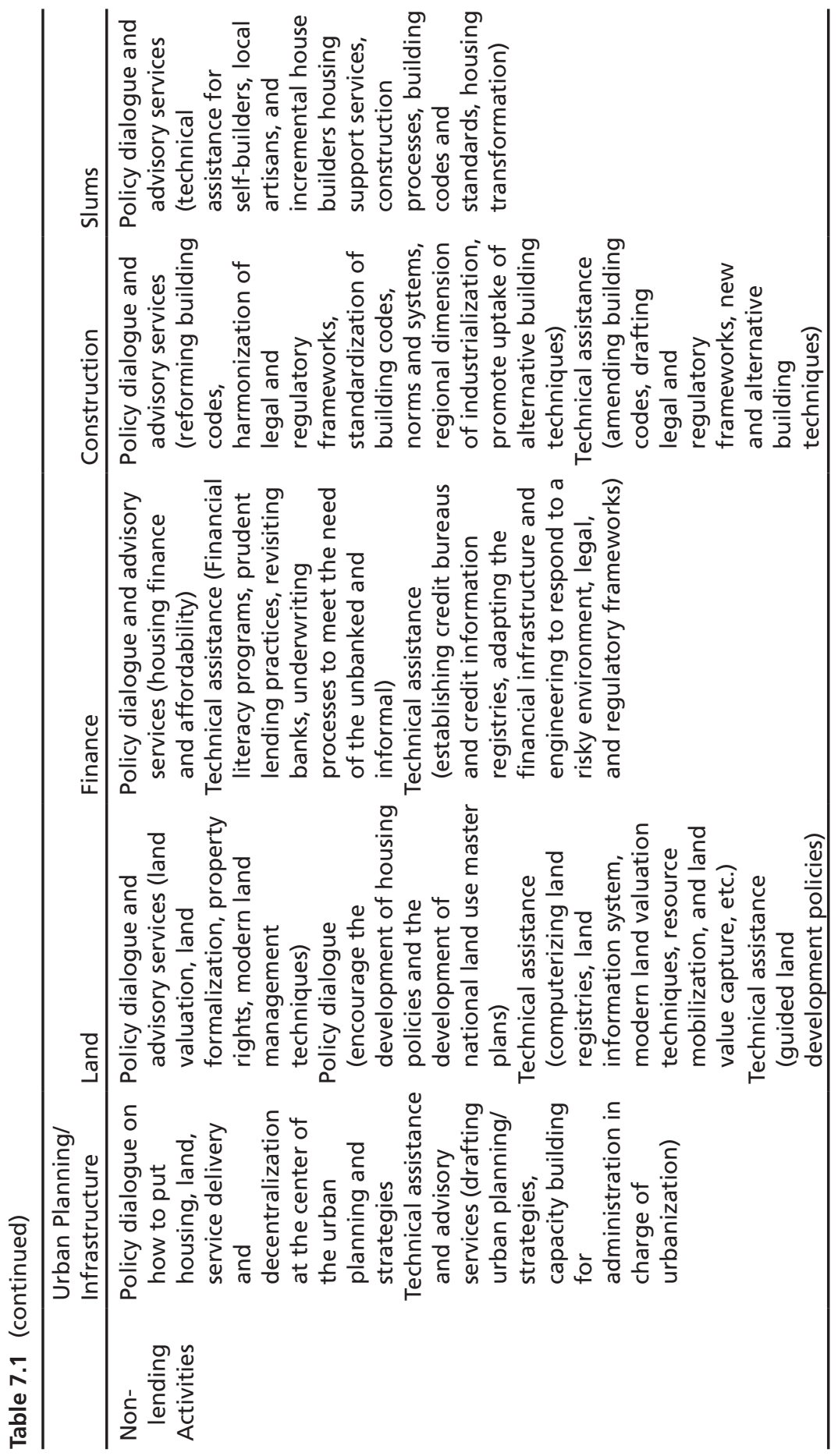


On the demand side, designing and implementing institutional, legal, and regulatory frameworks to promote access to long-term finance is critical for the development of housing finance. DFIs should assist governments in putting in place the right instruments for inclusive housing finance systems.

\subsubsection{Support Government in Its Role as an Input Provider}

Providing bulk infrastructure for new housing developments or slumupgrading programs requires large amounts of funding that may be hard to recover fully from land value capture, taxes, and the like. Hence, DFIs may need to assist by providing concessional funding to governments directly or by contributing to private sector stakeholders in PPPs. DFIs can also support governments by providing guarantee schemes for fundraising instruments such as municipal or infrastructure bonds.

\subsubsection{Support Affordable Housing Developers}

Initiatives such as the US\$300 million IFC-CITIC platform that works with local housing companies to develop affordable housing projects should be supported. Technical assistance and capacity-building initiatives that strengthen the core skills of local developers to raise capital for affordable housing and facilitate knowledge sharing are ways to ensure that high-quality housing is produced at lower cost. Providing developers with equity finance will help alleviate their financial constraints, which will inherently increase private-sector investment in the production of affordable housing for all income segments.

\subsubsection{Promote the Broadening and Deepening of Housing Finance in Africa}

In addition to effective institutional, legal, and regulatory frameworks, the development of housing finance requires not only long-term financing but also adequate financial instruments to mobilize and deploy funding. 


\subsubsection{Assist in the Development of Secondary Mortgage Markets}

The scarcity of long-term financing is one of the biggest constraints cited by banks in explaining their limited financing of the housing sector. Institutions with long-term funds, such as pension funds and insurance companies, are often prevented from investing in housing or lack proper instruments for investing. DFIs need to work with financial sectors and governments to develop those instruments. This effort should include the development of secondary mortgage markets.

In recent years, a number of countries—for instance, Egypt, Nigeria, Tanzania, and those in the West African Economic and Monetary Union-have set up mortgage refinancing companies with the help of the World Bank Group. Although this is a welcome development, the companies are limited by the deployment of shareholders' capital subscriptions or funds raised through bonds issuance, in some cases at high costs. The secondary mortgage market should be further developed to include securitization and listing in financial markets. This will allow greater participation by financial actors and will improve liquidity. DFIs should assist countries or regional markets in putting in place the necessary regulations and instruments. Guarantee schemes can also be provided to reduce the risks for a nascent market.

Real estate investment trusts (REITs) and mortgage-covered bonds are other cost-efficient instruments that provide the housing market with long-term funding, as well as open up investment opportunities for longterm institutional investors such as pension fund and insurance companies.

\subsubsection{Provide Funding to Financial Intermediaries}

Before supporting the full development of housing finance with a wellfunctioning and liquid secondary market, DFIs should provide longterm funding to financial intermediaries for on-lending to households. DFIs can also provide risk mitigation products to enable financial intermediaries to raise long-term funding. Such support can lower funding costs and hence lending rates for borrowers, which is important in mak- 
ing housing affordable. However, DFIs must be vigilant to ensure that households benefit from the preferential lending rates given to financial intermediaries.

Only high-income households are fully served by the current housing finance market. As such, the bulk of direct support by DFIs should be aimed at improving access and lowering financing costs for low-income and underserved markets. Credit enhancement facilities for the lowincome and underserved markets will promote a more inclusive housing finance market.

DFIs should also support MFIs, which can offer products more suitable to the building process and livelihoods of low-income households. Today, microfinance housing products are not well developed within the continent as they are limited by the scarcity of funding and by high interest rates. However, there are interesting models, which were discussed in Chap. 2. Beyond financial support to MFIs, DFIs should provide technical assistance and encourage partnerships models. Bank-MFI partnerships will contribute to eliminating the financing constraint faced by MFIs, thereby enabling them to serve a swath of low-income customers while opening new markets for banks. Other partnerships could include the self-help group-bank linkage model and partnerships between NBFIs and MFIs. However, the focus should be on building sustainable and scalable systems.

\subsection{Conclusion}

In recent years, many governments have announced measures to tackle the housing crisis in their countries. However, tangible action steps have not accompanied most of these public pronouncements. The role of the government in creating an enabling environment for the housing sector is extremely critical. As demonstrated in Morocco and Ethiopia, governments cannot reach their goals of affordable housing provision with partial solutions. The provision of affordable housing depends in particular on the strong and unwavering political will of governments, as well as the development and implementation of effective housing policies. Achieving this and these policies will require strengthening the coordination among 
public institutions and government ministries that play a role in housing, including ministries of finance.

In view of the housing challenges catalogued in preceding chapters, it is clear that African governments on their own cannot resolve the continent's housing crisis. There is an urgent and growing need for development partners and the private sector to join government efforts to tackle the crisis. This book has provided an orientation for housing stakeholders to the identification, design, and implementation of housing sector operations. Pursuing some of the policies proposed here can help overcome the policy, regulatory, and structural barriers to addressing Africa's housing crisis. 
Open Access This chapter is licensed under the terms of the Creative Commons Attribution 4.0 International License (http://creativecommons.org/licenses/ by/4.0/), which permits use, sharing, adaptation, distribution and reproduction in any medium or format, as long as you give appropriate credit to the original author(s) and the source, provide a link to the Creative Commons license and indicate if changes were made.

The images or other third party material in this chapter are included in the chapter's Creative Commons license, unless indicated otherwise in a credit line to the material. If material is not included in the chapter's Creative Commons license and your intended use is not permitted by statutory regulation or exceeds the permitted use, you will need to obtain permission directly from the copyright holder.

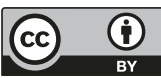

